\title{
An Evaluation of the Relationship Between Disease Severity and the Hematological, Biochemical and Hormone Values in Adult Patients with Obstructive Sleep Apnea Syndrome: A Cross-sectional Study
}

\author{
Obstrüktif Uyku Apne Sendromlu Erișkin Hastalarda Hematolojik, Biyokimyasal ve \\ Hormon Değerleri ile Hastalık Șiddeti Arasındaki Ilișkinin Değerlendirilmesi: Kesitsel \\ Bir Çalıșma
}

\author{
(1) Mustafa Avcu, (D) Mehmet Metin, (1) Harun Soyalıç, (1) Bilal Illanbey*, (D) Elvan Evrim Tuna \\ Ahi Evran University Training and Research Hospital, Clinic of Otorhinolaryngology, Kırşehir, Turkey \\ *Ahi Evran University Training and Research Hospital, Clinic of Biochemistry, Kırşehir, Turkey
}

\begin{abstract}
Objective: The aim of this study was to assess the effect on various systems of increased Obstructive Sleep Apnea syndrome (OSAS) severity, defined with the Apnea-hypopnea index (AHI).

Materials and Methods: The study was conducted on 245 patients who met the inclusion criteria. A total of 8 non-obese obese and obese non-obese groups were formed. There were the non-obese control group [AHI<5, Body Mass index (BMI) $\left.\leq 29.9 \mathrm{~kg} / \mathrm{m}^{2}(\mathrm{n}=32)\right]$, obese control group $\left[A H \mathrm{~K}<5, B M l>30 \mathrm{~kg} / \mathrm{m}^{2}(\mathrm{n}=28)\right]$, non-obese mild OSAS group [AHI 5-15, BMI $\left.\leq 29.9 \mathrm{~kg} / \mathrm{m}^{2}(\mathrm{n}=33)\right]$, obese mild OSAS group [AHI 5-15, BMl $\left.>30 \mathrm{~kg} / \mathrm{m}^{2}(\mathrm{n}=26)\right]$, non-obese moderate OSAS group [AHI 15-30, BMI $\left.\leq 29.9 \mathrm{~kg} / \mathrm{m}^{2}(\mathrm{n}=41)\right]$, obese moderate OSAS group [AHI $15-30, \mathrm{BMl}>30 \mathrm{~kg} / \mathrm{m}^{2}(\mathrm{n}=24)$ ], non-obese severe OSAS group [AHl> $\left.30, B M I \leq 29.9 \mathrm{~kg} / \mathrm{m}^{2}(\mathrm{n}=38)\right]$, and obese severe OSAS group [AHI $>30$, $\left.\mathrm{BMl}>30 \mathrm{~kg} / \mathrm{m}^{2}(\mathrm{n}=23)\right]$.

Results: A statistically significantly greater difference was determined between the groups in respect of the monocyte HDL cholesterol ratio (MHR), monocyte LDL cholesterol ratio (MLR) and uric acid excretion (UAE) values together with an increase in the severity of OSAS $(p<0.001$, $\mathrm{p}<0.001$ and $\mathrm{p}=0.006$, respectively).

There was a positive correlation of OSAS severity with MHR ( $r=0.671$, $\mathrm{p}=0.001), \mathrm{UAE}(\mathrm{r}=0.467, \mathrm{p}=0.001)$ and triglyceride $(\mathrm{r}=0.304, \mathrm{p}=0.001)$ values and a negative correlation with MLR $(r=-0.213, p=0.001)$ and $\mathrm{HDL}$ cholesterol $(\mathrm{r}=-0.285, \mathrm{p}=0.001)$ values. Linear regression analysis identified that triglycerides $(\mathrm{mg} / \mathrm{dL})$, UA excretion $(\mathrm{mg} / \mathrm{dL})$, neutrophil lymphocyte ratio, MHR and MLR significantly contributed to OSAS severity.

Conclusion: The increasing severity of OSAS, which has a multifactorial etiology, affects many systems, primarily the inflammatory and cardiac systems.

Keywords: Obstructive sleep apnea, hematological parameters, monocyte $\mathrm{HDL}$ ratio, monocyte $\mathrm{LDL}$ ratio, uric acid excretion
\end{abstract}

Öz

Amaç: Bu çalışmada, Apne-hipopne indeksi (AHI) ile tanımlanan Obstrüktif Uyku Apne sendromu (OSAS) şiddetindeki artışın farklı sistemler üzerine olan etkilerinin değerlendirilmesi amaçlanmıştır.

Gereç ve Yöntem: Çalışma, dahil edilme şartlarını karşılayan toplam 245 hasta üzerinde yapıldı. Hastalar, hastalık şiddeti ve Vücut Kitle Indeksi (VKI) değerleri göz önünde bulundurularak obez ve non-obez toplam 8 gruba ayrıldı. Non-obez kontrol grubu $\left[A H \mathrm{i}<5, \mathrm{VKI} \leq 29,9 \mathrm{~kg} / \mathrm{m}^{2}(\mathrm{n}=32)\right]$ obez kontrol grubu $\left[\mathrm{AHI}<5, \mathrm{VKI}>30 \mathrm{~kg} / \mathrm{m}^{2}(\mathrm{n}=28)\right]$; non-obez hafif OSAS grubu [AHI 5-15, VKI $\leq 29,9 \mathrm{~kg} / \mathrm{m}^{2}(\mathrm{n}=33)$ ]; obez hafif OSAS grubu [AHI $5-15, V K i>30 \mathrm{~kg} / \mathrm{m}^{2}(\mathrm{n}=26)$ ]; non-obez orta şiddette OSAS grubu [AHI 15-30, VKI $\leq 29,9 \mathrm{~kg} / \mathrm{m}^{2}(\mathrm{n}=41)$ ]; obez orta şiddette OSAS grubu [AHI $\left.15-30, \mathrm{VKI}>30 \mathrm{~kg} / \mathrm{m}^{2}(\mathrm{n}=24)\right]$; non-obez ciddi OSAS grubu [AHI $>30$, $\left.\mathrm{VKI} \leq 29,9 \mathrm{~kg} / \mathrm{m}^{2}(\mathrm{n}=38)\right]$; obez ciddi OSAS grubu [AHI $>30, \mathrm{VKI}>30 \mathrm{~kg} /$ $\left.\mathrm{m}^{2}(\mathrm{n}=23)\right]$.

Bulgular: Gruplar arasında monosit HDL kolesterol oranı (MHRs), monosit LDL kolesterol oranı (MLRs) ve ürik asit ekskresyon (UAE) değerlerindeki farkın, OSAS şiddeti artışı ile anlamlı oranda arttığı görüldü (sırasıyla $p<0,001, p<0,001$ ve $p=0,006$ ). OSAS şiddeti ile biyokimyasal ve hemotolojik parametreler arasındaki ilişki korelasyon analizleriyle değerlendirildiğinde MHRs $(r=0,671, p=0,001)$ ve UAE $(r=0,467, p=0,001)$ ve trigliserid $(r=0,304, p=0,001)$ değerleri ile pozitif korelasyon olduğu, MLRs $(r=-0,213, p=0,001)$ ve HDL kolesterol $(r=-$ $0,285, p=0,001$ ) değerleri ile de negatif korelasyon olduğu görüldü. Lineer regresyon analizlerinde trigliserid $(\mathrm{mg} / \mathrm{dL})$, UA ekskresyon $(\mathrm{mg} /$ $\mathrm{dL}$ ), nötrofil lenfosit oranı, MHRs ve MLRs değerlerinin OSAS şiddetine anlamlı katkı sağladığı tespit edildi.

Sonuç: Multifaktöriyel etiyolojiye sahip olan OSAS, artan şiddetiyle birlikte başta enflamatuvar ve kardiyak olmak üzere pek çok sistemi de etkilemektedir.

Anahtar Kelimeler: Obstrüktif uyku apnesi, hematolojik parametreler, monosit HDL oranı, monosit LDL oranı, ürik asit ekskresyonu 


\section{Introduction}

Obstructive Sleep Apnea syndrome (OSAS) is a very common disease affecting nearly $17 \%$ of the adult population (1). OSAS is known to cause increased morbidity and mortality related to many systems and diseases such as cardiovascular disease, obesity, dyslipidemia, coronary artery disease, arterial hypertension, type 2 diabetes, congestive heart failure and cerebrovascular events (2). Recent studies have suggested that various inflammatory mediators (3-5), biochemical markers (6-8) and hormonal parameters (9-11) are associated with the disease or disease severity. However, it is not clear whether the increase in disease severity in OSAS patients affects other systems or whether disorders of other systems cause OSAS. It is most likely that this is a two-way process and both situations cause increases in the severity of the other. For example, the underlying mechanisms of cardiovascular system pathologies are considered to be sympathetic nervous system hyperactivity, oxidative stress, vascular endothelial dysfunction and metabolic dysregulation. However, disrupted cardiac functions cause an increase in OSAS severity (12). Previous studies in literature, have generally focused on the disruption of various parameters increasing OSAS severity, but there is no study which has assessed the effects of increased OSAS severity on different systems and diseases, or which system is most affected. The aim of this study was to assess the effect on different systems of increased OSAS severity, defined with the Apnea-hypopnea index ( $\mathrm{AHI})$.

\section{Materials and Methods}

\section{Setting and Patients}

Approval for this prospective study was granted by the Local Ethics Committee (decision no: 2018-15/105) and all procedures were applied in accordance with the 1975 Helsinki Declaration. The study included a total of 245 consecutive patients, aged 18-65 years, with complaints of daytime napping and/or snoring who presented at the clinic between 01.02.2018 and 15.12.2018. Written consent was obtained from all the study participants.

The patients included were those diagnosed with OSAS, aged 18-65 years, with no comorbid systemic disease, had no history of psychotropic drug use or illegal drug use and/or consumed $<5 \mathrm{~g}$ units of alcohol, and had not been engaged in shift work in the previous 4 weeks or taken a transmeridian flight.

Exclusion criteria for the study were (1) other sleeping disorders such as Central Sleep Apnea syndrome, narcolepsy, Upper Airway Resistance syndrome, or Restless Legs syndrome, (2) hypertension, thyroid replacement treatment, diabetes mellitus, history of medical treatment for hyperlipidemia or any active infection or any inflammatory disease, (3) administration of continuous positive airway pressure or previous surgical intervention due to OSAS, (4) any hepatic, pulmonary, renal or cardiac failure, (5) surgical upper respiratory tract pathology causing Sleep Apnea syndrome, (6) those with endothelial functions, systemic inflammation or oxidative stress parameters which could affect the results, those who smoked, drank $>5 \mathrm{~g}$ units of alcohol and/or used illegal drugs, (7) those who had been engaged in shift work or taken a transmeridian flight in the previous 4 weeks, which could change the sleep parameters and the hematological parameters evaluated in the study, and (8) patients not wishing to participate in the study.

\section{Anthropometric and Blood Pressure Measurements}

Body Mass index (BMI) was calculated by dividing the body mass by the square of height $\left(\mathrm{kg} / \mathrm{m}^{2}\right)$. Daytime systolic and diastolic blood pressure was measured with a mercury blood pressure device at 8.00 in the morning after 5 minutes rest in a sitting position. The mean value of three measurements was recorded. Detailed physical examination was performed to assess anatomic variations that may cause Sleep Apnea syndrome.

\section{Biochemical, Hematologic, Urine and Hormone Parameter Measurements}

Many studies have used hemocytic parameters shown to be associated with disease severity such as neutrophil lymphocyte ratio (NLR), platelet lymphocyte ratio (PLR) (2-5), monocyte count/high density lipoprotein (HDL) cholesterol ratio (MHR) (7) and monocyte count/low density lipoprotein (LDL) cholesterol ratio (MLR) to assess inflammatory status. Lipid panel [LDL $(\mathrm{mg} / \mathrm{dL}), \mathrm{HDL}(\mathrm{mg} / \mathrm{dL})$, triglyceride $(\mathrm{mg} / \mathrm{dL})$, total cholesterol $(\mathrm{mg} / \mathrm{dL})$ ] was used to assess the cardiovascular system $(6,7)$. The effects on the liver were assessed by examining glutamyl transferase (GGT) (U/L) and alkaline phosphatase (ALP) (U/L) levels (8). Serum thyroid stimulating hormone (TSH) $(\mu \mathrm{IU} / \mathrm{mL})$ levels were assessed to evaluate the effects on the thyroid. The $1.25(\mathrm{OH}) \mathrm{D}_{3}(\mathrm{nmol} / \mathrm{L})$ levels were examined as they are known to affect different systems in OSAS patients including increased systemic inflammation, dyslipidemia and bone deformation, in addition to cardiovascular diseases (13). With the aim of assessing cellular hemostasis levels the potential marker of tissue hypoxia of the ATP degradation product of uric acid excretion (UAE) (mg/dL) was assessed. UAE was calculated using the uric acid (UA) serum creatinine and urine creatinine levels with the formula "UAE = (urinary UA/urinary creatinine) $X$ serum creatinine" (14).

Before taking blood and urine samples from the patients, detailed systemic questioning and a physical examination were performed to assess the presence of infection. Patients considered to have infection on physical examination and with high white cell counts were called for check-up at least 1 month after treatment and if no infection was detected, fasting blood and urine samples were taken at 08:00 -10:00 hours following a 10-minute rest from 8-10 in an environment at mean $+20^{\circ} \mathrm{C}$. Routine clinical chemistry and immunoassay parameters were measured using standard laboratory methods (Cobas 8000; Roche Diagnostics ${ }$, Germany). Hematological parameters were determined using a Sysmex XN-1000 automated blood cell counter (Sysmex Corporation, Kobe, Japan). 


\section{Epworth Sleepiness Scale and Polysomnography Monitoring}

To assess the patient's tendency to sleepiness, the Turkish version of the Epworth Sleepiness scale was used. The scale comprises eight items, each scored from 0 to 3 points, giving a total score of $0-24$.

To objectively assess the night sleeping status of each participant, the in-laboratory Philips Respironics Alice 5, 2016, USA device was used according to the American Academy of Sleep Medicine 2007 criteria. The assessment parameters in brief are nasal and oral air flow (using both nasal oral thermocouple and nasal pressure cannula), snoring sounds, thoracic/abdominal movements, oxygen saturation, leg movements and body position, $\mathrm{AHI}$ and Oxygen Desaturation index (ODI). Scoring is automatically calculated by the computer software and was later manually checked by a technician.

Apnea is defined as more than $90 \%$ of air flow being stopped for at least 10 seconds. Hypopnea is defined as $\geq 50 \%$ reduction in airflow for 10 seconds or longer related to $\geq 3 \%$ oxygen desaturation or stimulus. Stimuli are defined as sudden slides in electroencephalographic frequency lasting at least 3 secs. AHI is defined as the number of apnea and hypopnea events and severity of OSAS is assessed according to AHI. It is categorized as normal $(<5)$, mild (5-14.9), moderate $(15-29.9)$ or severe $(\geq 30)$.

The patients were divided into 8 groups according to disease severity and BMI values; the non-obese control group $[\mathrm{AHI}<5$, $\left.B M I \leq 29.9 \mathrm{~kg} / \mathrm{m}^{2}(\mathrm{n}=32)\right]$, obese control group $[\mathrm{AHI}<5, \mathrm{BMl}>30$ $\left.\mathrm{kg} / \mathrm{m}^{2} \quad(\mathrm{n}=28)\right]$, non-obese mild OSAS group [AHI 5-15, BMI $\leq 29.9 \mathrm{~kg} / \mathrm{m}^{2}(\mathrm{n}=33)$ ], obese mild OSAS group [AHI 5-15, $\left.\mathrm{BMI}>30 \mathrm{~kg} / \mathrm{m}^{2}(\mathrm{n}=26)\right]$, non-obese moderate OSAS group [AHI $\left.15-30, B M l \leq 29.9 \mathrm{~kg} / \mathrm{m}^{2}(\mathrm{n}=41)\right]$, obese moderate OSAS group [AHI 15-30, BMl $\left.30 \mathrm{~kg} / \mathrm{m}^{2}(\mathrm{n}=24)\right]$, non-obese severe OSAS group [AHI $\left.>30, B M l \leq 29.9 \mathrm{~kg} / \mathrm{m}^{2}(\mathrm{n}=38)\right]$ and OSAS group [AHI $\left.>30, \mathrm{BMl}>30 \mathrm{~kg} / \mathrm{m}^{2}(\mathrm{n}=23)\right]$. The age, gender, $\mathrm{BMI}\left(\mathrm{kg} / \mathrm{m}^{2}\right)$, Epworth, Müller, Mallampati scores, NLR, PLR, MHR, MLR, LDL $(\mathrm{mg} / \mathrm{dL}), \mathrm{HDL}(\mathrm{mg} / \mathrm{dL})$, triglycerides $(\mathrm{mg} / \mathrm{dL})$, total cholesterol $(\mathrm{mg} / \mathrm{dL})$, GGT $(\mathrm{U} / \mathrm{L}), \operatorname{ALP}(\mathrm{U} / \mathrm{L})$, serum TSH $(\mathrm{u} \mathrm{IU} / \mathrm{mL}), \mathrm{UAE}$ $(\mathrm{mg} / \mathrm{dL}), 25(\mathrm{OH}) \mathrm{D}(\mathrm{nmol} / \mathrm{L})$, systolic blood pressure $(\mathrm{mm} / \mathrm{Hg})$, diastolic blood pressure $(\mathrm{mm} / \mathrm{Hg})$, mean $\mathrm{O}_{2}$ saturation, minimal $\mathrm{O}_{2}$ saturation and $\mathrm{O}_{2} \mathrm{ODI}$ of all the patients were prospectively recorded.

\section{Statistical Analysis}

Data obtained in the study were analyzed statistically using IBM SPSS for Windows, version 17.0 software (IBM Corporation, Armonk, NY, USA). Results were stated as mean \pm standard deviation values. The ANOVA test (ANOVA with Tukey HSD) was applied to the comparisons of multiple groups. A value of $p<0.05$ was accepted as statistically significant. Linear regression models were used to assess factors related to OSAS. Optimal cut-off values for the diagnosis of OSAS for each variable were determined with receiver operating characteristic (ROC) curves. The area under the curve (AUC) represents the 95\% confidence interval $(\mathrm{Cl})$. Combinations of biomarkers were determined again with ROC curves and the AUC values were re-assessed in terms of prognostic determination of the multiple multi-marker approach. Re-classification analyses using net reclassification improvement (NRI) and integrated discrimination improvement (IDI) were used to assess the added value of the multi-marker approach to (LDL cholesterol, $\mathrm{HDL}$ cholesterol, triglyceride, total cholesterol), (NLR,PLR, MHRs, MLRs), (GGT and ALP) and [serum TSH, UAE, 25(OH) D]. The NRI and IDI values were analyzed at $95 \% \mathrm{Cl}$. For the statistical analyses, MedCalc Software (version 15.8, MedCalc Software, Mariakerke, Belgium) and $\mathrm{R}$ version 3.3.1 (The $\mathrm{R}$ Foundation for Statistical Computing, Vienna, Austria) were used. The $p$-values were not adjusted for multiple comparisons and, therefore, were only descriptive.

\section{Results}

The clinical features of the patients included in the study are summarized in Table 1. When the 245 patients were assessed in terms of age, systolic blood pressure and diastolic blood pressure values, no statistically significant difference was observed (all $p>0.05)$. A statistically significant difference was determined between the patients in terms of gender $(p=0.031)$. In the intra-group comparisons, there was no significant difference between the control groups and mild OSAS patient groups, and male gender was found to be dominant in the severe and moderate severity OSAS patient groups. When patients were assessed in terms of biochemical, hematological and hormone values that have been shown to be significantly associated with increased OSAS severity in previous studies, no difference was determined between the groups in terms of ALP and vitamin $D$ values ( $p>0.05$ for all). The differences in MHR, MLR and UA excretion values were found to be highly statistically significant $(p<0.001, p<0.001$ and $p=0.006$, respectively) (Table 2$)$.

When the correlation between OSAS severity and biochemical and hematological parameters was assessed, MHR ( $r=0.671$, $\mathrm{p}=0.001)$, UA excretion $(\mathrm{r}=0.467, \mathrm{p}=0.001)$ and triglyceride $(r=0.304, p=0.001)$ values were positively correlated and MLR $(r=-0.213, p=0.001)$ and HDL cholesterol $(r=-0.285, p=0.001)$ values were negatively correlated. When separate evaluations were made of the obese and non-obese groups, the positive MHR and the negative MLR correlations in the obese groups were strengthened. The factors associated with OSAS severity are shown in Table 3.

Linear regression analysis of the biochemical variables correlated with OSAS severity was applied to assess the contribution of multiple common variables to OSAS severity. First, all groups were assessed together, as in the correlation analyses, and triglycerides (mg/dL), UA excretion ( $\mathrm{mg} / \mathrm{dL}), \mathrm{NLR}, \mathrm{MHR}$ and MLR values were determined to significantly contribute to OSAS severity. The obese and non-obese groups were then assessed separately and with the exception of triglycerides in the obese group and MLR in the non-obese group, all variables were observed to significantly contribute to OSAS severity. The variables are shown in Table 4. 
Avcu et al.

Obstructive Sleep Apnea Syndrome Severity on Biochemical Parameters
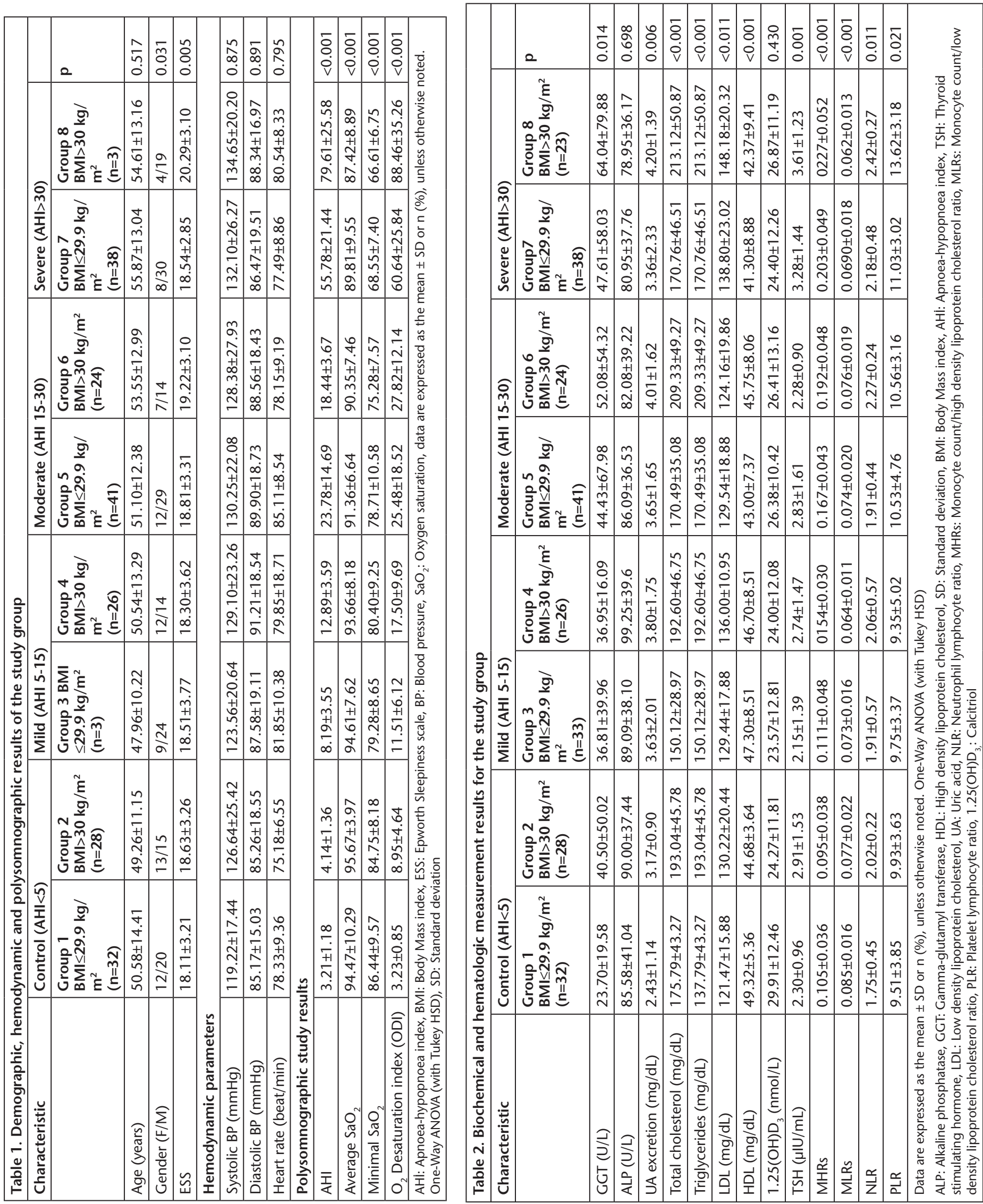
Avcu et al.

Obstructive Sleep Apnea Syndrome Severity on Biochemical Parameters

\begin{tabular}{|c|c|c|c|c|c|c|}
\hline \multicolumn{7}{|l|}{ OSAS severity } \\
\hline & \multicolumn{2}{|c|}{ All patients $(n=245)$} & \multicolumn{2}{|c|}{ Non-obese patients $(n=144)$} & \multicolumn{2}{|c|}{ Obese patients $(n=101)$} \\
\hline & $\mathbf{r}$ & $p$ & $\mathbf{r}$ & $p$ & $r$ & $p$ \\
\hline GGT (U/L) & $0.186^{*}$ & 0.046 & 0.063 & 0.428 & $0.223^{*}$ & 0.045 \\
\hline $\operatorname{ALP}(\mathrm{U} / \mathrm{L})$ & 0.044 & 0.542 & 0.055 & 0.487 & 0.153 & 0.181 \\
\hline UA excretion (mg/dL) & $0.467^{* *}$ & 0.001 & $0.282^{\star *}$ & 0.001 & $0.482^{* *}$ & 0.001 \\
\hline Total cholesterol (mg/dL) & 0.059 & 0.364 & 0.017 & 0.831 & 0.187 & 0.102 \\
\hline Triglycerides (mg/dL) & $0.304^{\star \star}$ & 0.001 & $0.365^{\star *}$ & 0.001 & $0.233^{*}$ & 0.042 \\
\hline $\mathrm{LDL}(\mathrm{mg} / \mathrm{dL})$ & $0.249^{* *}$ & 0.001 & $0.235^{\star *}$ & 0.008 & $0.293^{*}$ & 0.010 \\
\hline $\mathrm{HDL}(\mathrm{mg} / \mathrm{dL})$ & $-0.285^{\star \star}$ & 0.001 & $-0.361^{\star *}$ & 0.001 & -0.135 & 0.239 \\
\hline $25(\mathrm{OH}) \mathrm{D}(\mathrm{nmol} / \mathrm{L})$ & -0.058 & 0.371 & -0.143 & 0.069 & 0.101 & 0.377 \\
\hline $\mathrm{TSH}(\mu \mathrm{IU} / \mathrm{mL})$ & $0.230^{\star *}$ & 0.001 & $0.272^{\star \star}$ & 0.001 & 0.170 & 0.141 \\
\hline MHRs & $0.671^{* *}$ & 0.001 & $0.629^{* *}$ & 0.001 & $0.769^{* *}$ & 0.001 \\
\hline MLRs & $-0.273^{* \star}$ & 0.001 & $-0.220^{\star \star}$ & 0.005 & $-0.346^{\star \star}$ & 0.002 \\
\hline NLR & $0.295^{* *}$ & 0.001 & $0.278^{* *}$ & 0.001 & $0.426^{* *}$ & 0.001 \\
\hline PLR & $0.272^{\star *}$ & 0.002 & 0.134 & 0.097 & $0.352^{\star *}$ & 0.002 \\
\hline \multicolumn{7}{|c|}{$\begin{array}{l}\text { ALP: Alkaline phosphatase, GGT: Gamma-glutamyl transferase, HDL: High density lipoprotein cholesterol, LDL: Low density lipoprotein cholesterol, NLR: Neutrophil } \\
\text { lymphocyte ratio, MHRs: Monocyte count/high density lipoprotein cholesterol ratio, MLRs: Monocyte count/low density lipoprotein cholesterol ratio, PLR: Platelet } \\
\text { lymphocyte ratio, TSH: Thyroid stimulating hormone, UA: Uric acid, } 1.25(\mathrm{OH}) \mathrm{D}_{3} \text { : Calcitriol }\end{array}$} \\
\hline
\end{tabular}

\begin{tabular}{|c|c|c|c|c|c|c|c|c|}
\hline \multicolumn{3}{|c|}{ All patients $(n=245)$} & \multicolumn{3}{|c|}{ Non-obese patients $(n=144)$} & \multicolumn{3}{|c|}{ Obese patients $(n=101)$} \\
\hline $\begin{array}{l}\text { Odds } \\
\text { ratio }\end{array}$ & $p$ & $(95 \% \mathrm{Cl})$ & $\begin{array}{l}\text { Odds } \\
\text { ratio }\end{array}$ & $p$ & $(95 \% \mathrm{Cl})$ & $\begin{array}{l}\text { Odds } \\
\text { ratio }\end{array}$ & $p$ & $(95 \% \mathrm{Cl})$ \\
\hline 0.146 & 0.006 & $(0.024-0.780)$ & 0.212 & 0.002 & $(0.002-0.314)$ & 0.046 & 0.527 & $(-0.003-0.063)$ \\
\hline 0.261 & 0.001 & $(0.001-0.314)$ & 0.333 & 0.001 & $(0.003-0.458)$ & 0.242 & 0.002 & $(0.041-0.553)$ \\
\hline 0.140 & 0.006 & $(0.057-0.851)$ & 0.114 & 0.014 & $(0.034-0.324)$ & 0.159 & 0.030 & $(0.048-0.890)$ \\
\hline-0.117 & 0.017 & $(0.013-0.228)$ & -0.118 & 0.062 & $(-0.469-0.323)$ & -0.148 & 0.033 & $(0.003-0.804)$ \\
\hline
\end{tabular}

The cut-off values for the diagnostic parameters determined with ROC analysis and the sensitivity and specificity for severe OSAS diagnosis are shown in Figures 1-4.

Re-classification analyses demonstrated that the combinations of hematological inflammatory parameters (NLR, PLR, MHR and MLR) and biochemical lipid parameters (triglycerides, total cholesterol, HDL and LDL) had high diagnostic correlation with OSAS severity, and liver enzyme values (GGT, ALP) had a low correlation (Figure 5).

\section{Discussion}

The aim of this study was to assess the effect on different systems of an increase in OSAS severity defined by the AHI. The biochemical, hematological and hormone values which have previously been identified to be associated with OSAS severity were used in these evaluations $(3-5,7-13,15)$. With the aim of not disrupting the homogeneity of the study results, groups were formed according to BMI values. The MLR value, which has not been used in any previous study, was examined for the first time and this parameter was shown to have a negative correlation with OSAS severity, similar to HDL. Multiple logistic regression analysis was performed to determine the cutoff values for each parameter showing an effect on OSAS severity. Re-classification analyses were applied to all groups together and separately to both obese and non-obese groups. The hematological parameters were seen to have a higher diagnostic correlation with OSAS severity compared to other groups.

Conflicting results have been obtained from studies assessing the correlation between OSAS severity and lipid profile (14). Some authors have emphasized a correlation between lipid levels and OSAS severity $(16,17)$, while others have claimed that dyslipidemia is linked to obesity rather than OSAS $(18,19)$. To the best of our knowledge, this is the first study to have grouped patients according to OSAS severity and obesity. This grouping aimed to differentiate clearly whether disruption of the 

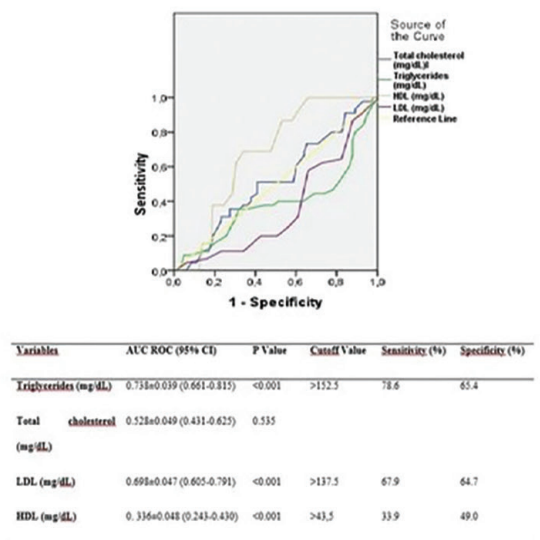

A
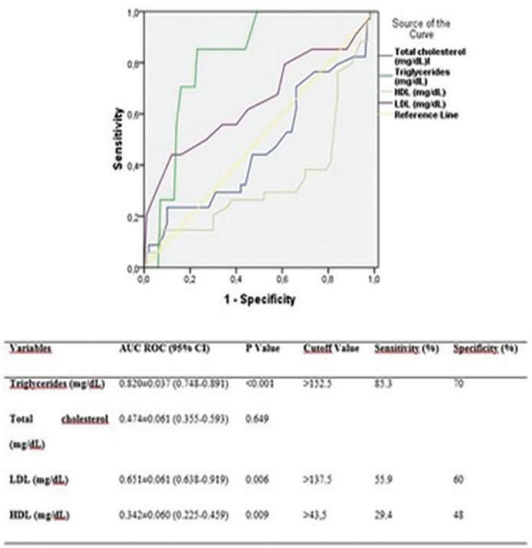

B
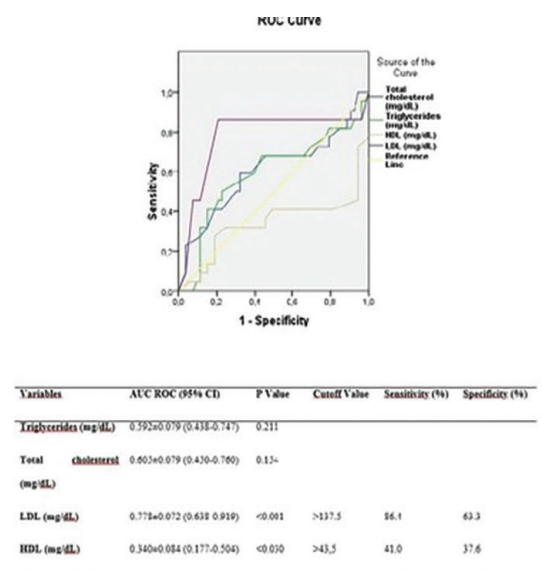

C

Figure 1. ROC curves and cut-off values for lipid profile panel in determination of severe OSAS patients A) obese and non-obese patient groups, B) obese patients, C) non-obese patients

ROC: Receiver operating characteristic, OSAS: Obstructive Sleep Apnoea sydrome
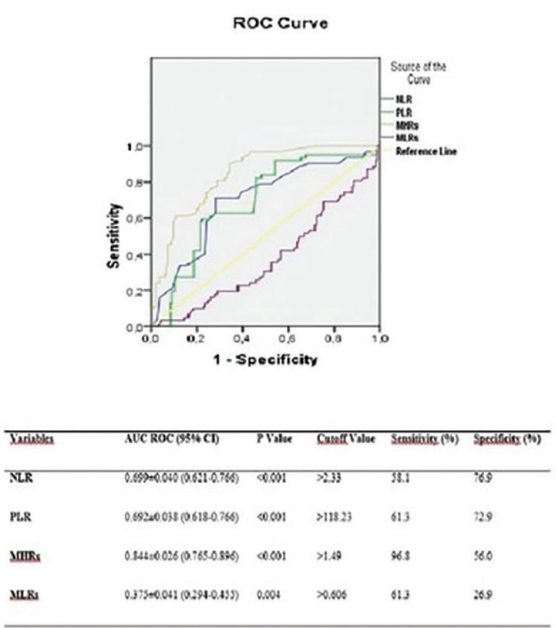

A

Figure 2. ROC curves and cut-off values for inflammatory panel in determination of severe OSAS patients $A$ ) obese and non-obese patient groups, B) obese patients, C) non-obese patients

ROC: Receiver operating characteristic, OSAS: Obstructive Sleep Apnoea syndrome

parameters was due to increased OSAS severity or obesity. When both the obese and non-obese groups were compared with the control groups, the lipid profile was seen to be significantly disrupted, and this disruption was more pronounced in obese patients. Correlation analyses demonstrated this correlation in all groups together and in the separate groups. However, when factors associated with OSAS severity were assessed with logistic regression analyses, only the triglyceride level from the lipid panel was identified as contributing to OSAS severity.
Elevated GGT has been shown to be associated with hepatobiliary dysfunction and alcohol abuse in addition to end-stage cardiac diseases, diabetes mellitus, hypertension, stroke and OSAS. Although many studies have assessed the correlation between OSAS and elevated liver enzymes, the underlying mechanism remains unclear $(8,20-22)$. However, the etiopathogenesis is affected by many variables such as cardiac and endothelial dysfunction, metabolic abnormalities, increased vascular stiffness due to autonomic cardiovascular 

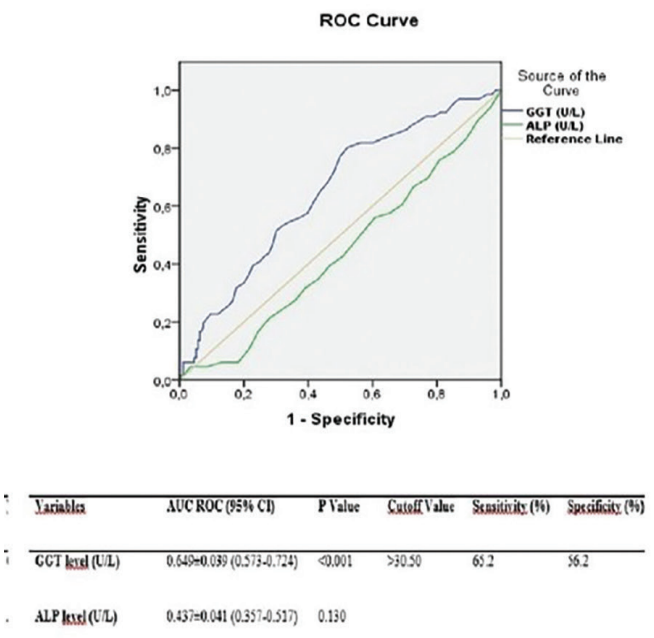

A
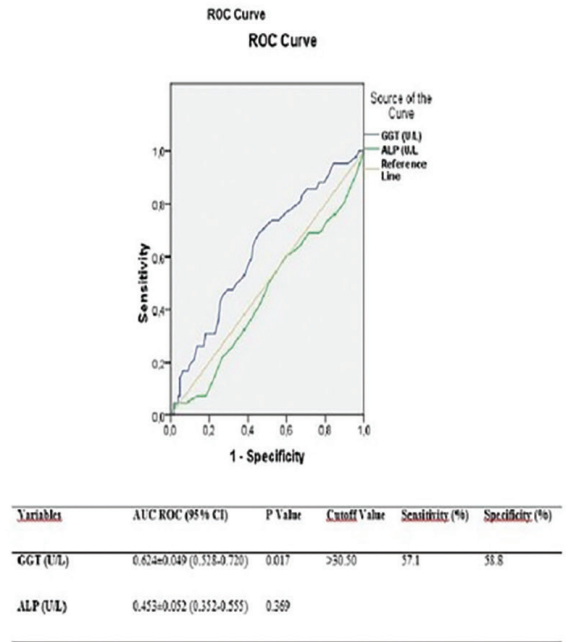

B
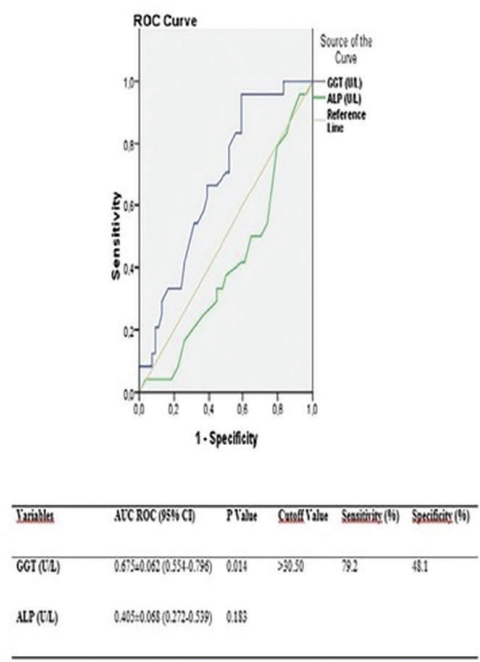

C

Figure 3. ROC curves and cut-off values for liver enzyme levels in determination of severe OSAS patients A) obese and non-obese patient groups, B) obese patients, C) non-obese patients

ROC: Receiver operating characteristic, OSAS: Obstructive Sleep Apnoea syndrome
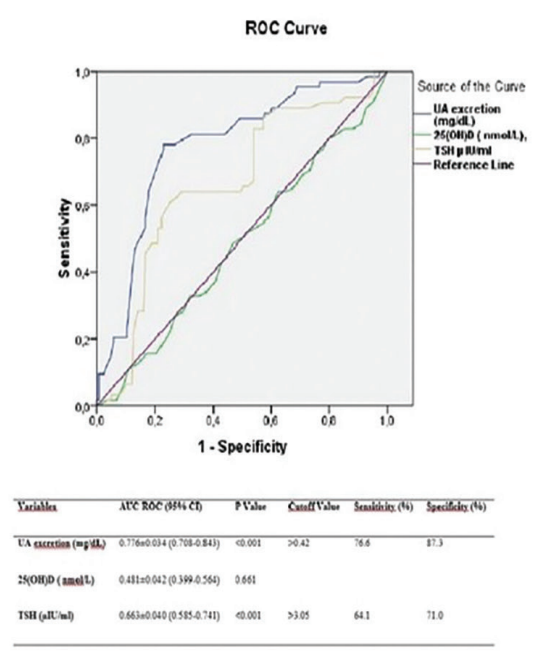

A

Figure 4. ROC curves and cut-off values for uric acid excretion in determination of severe OSAS patients A) obese and non-obese patient groups, B) obese patients, C) non-obese patients

ROC: Receiver operating characteristic, OSAS: Obstructive Sleep Apnoea syndrome

modulation, systemic inflammation and oxidative stress (8). In a study of 270 patients, Bozkus et al. (8) assessed the correlation between OSAS, hypertension and liver enzyme elevation and stated that the increase in OSAS severity was associated with increased GGT. Another study emphasized that probable liver steatosis associated with obesity caused an increase in liver GGT
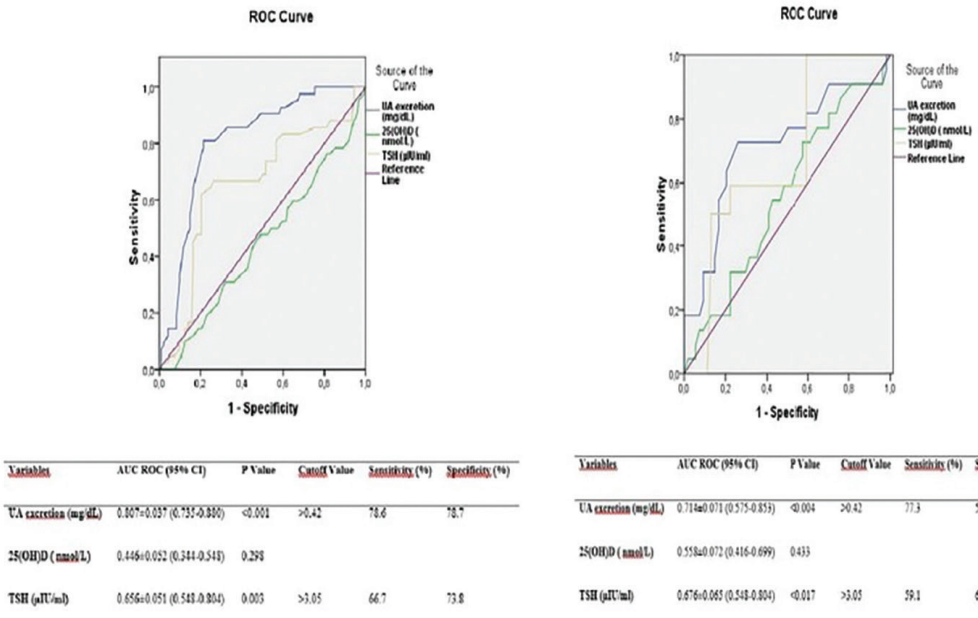

B

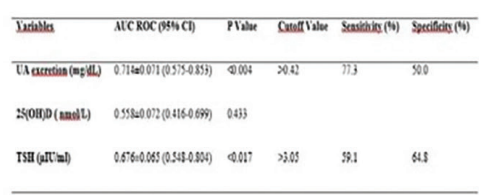

C 

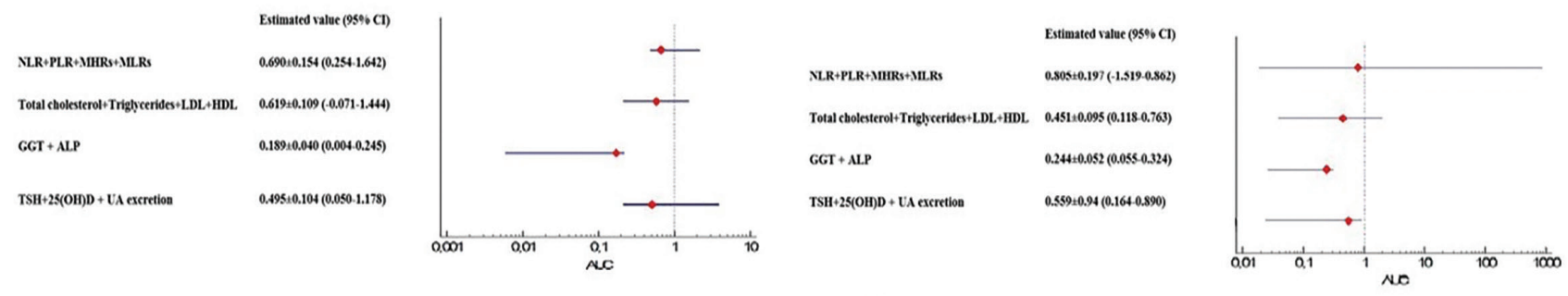

A

B

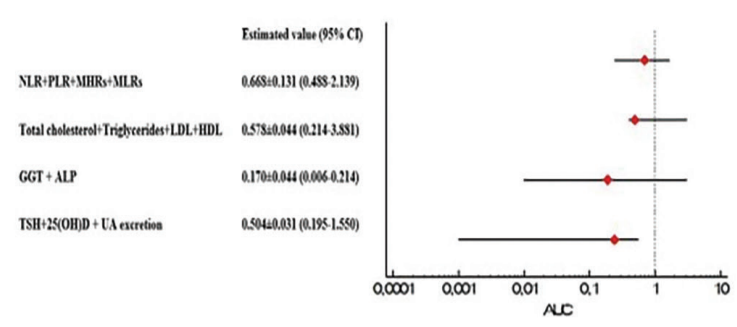

C

Figure 5. Assessment of factors related to OSAS severity with multi-marker approach. Biomarkers were reclassified using NRI and IDI. The rhombi mean values and lines are at $95 \% \mathrm{Cl}$

IDI: Integrated discrimination improvement, NRI: Net Reclassification index, OSAS: Obstructive Sleep Apnoea syndrome, CI: Confidence interval

the current study obese group and non-obese group with the control group, there was seen to be a significant increase in GGT levels, and this GGT elevation was more pronounced in obese patients. There was no difference between the groups in respect of ALP levels and correlation analysis showed no correlation between ALP levels and OSAS severity. The increase in GGT was correlated with OSAS severity in the obese and nonobese groups, in accordance with previous findings in literature, although no correlation was observed in the non-obese group. The increase in GGT can be considered to be associated with obesity.

UA is a stable chemical among the ATP degradation products, which is simple and cheap to measure, and has recently been shown to be associated with hypoxia in OSAS patients (15). Ozanturk et al. (15), evaluated 75 patients in respect of the correlation between nocturnal normohypoxia and nocturnal hypoxia with UAE and reported that UA excretion was significantly higher in the nocturnal hypoxia group. Hirotsu et al. (24) emphasized that it was not an appropriate biomarker, as there was a strong relationship of hyperuricemia with OSAS and therefore, UA metabolites should be considered in the management of sleep apnea (24). In the current study, the correlation between UAE and OSAS severity was assessed and thyroid hormone levels and vitamin D levels in this panel. Some previous studies have shown that both markers are associated with OSAS severity. In the current study, no correlation was identified between vitamin D and OSAS severity, while there was a correlation between TSH levels and OSAS severity. Of the parameters evaluated in this study, the parameter with the second strongest correlation with OSAS severity was UAE. Subgroup analysis identified this strong correlation in both the obese groups and non-obese groups. Logistic regression analysis demonstrated that UAE values contributed to OSAS severity. These results were seen to be consistent with previous findings reported in the literature.

Finally, the correlation between systemic inflammation and OSAS severity was assessed in this study, using a panel which included NLR, PLR and MHR. To the best of our knowledge, MLR has not been assessed in any previous study, so this was evaluated for the first time to determine whether it contributed to OSAS severity. OSAS and OSAS-linked intermittent hypoxia are known to cause inflammation, oxidative stress and endothelial dysfunction, which are held responsible for cardiovascular diseases associated with OSAS (8). In these types of conditions, some studies have reported that HDL cholesterol contributes to the body's defence system $(7,25)$. MHR is a new cardiovascular prognostic marker that has recently been the focus of attention as a consequence of an association with severe cardiovascular diseases seen at an increased rate in the general population $(26,27)$. A recent study clearly revealed a correlation between increased MHR and OSAS severity (7). LDL cholesterol, unlike HDL cholesterol, is a well-known biochemical marker with oxidant activity $(7,25)$. However, to date there has been no study in literature which has examined the correlation of OSAS severity with monocyte and LDL cholesterol. The results of the 
current study showed that the biomarker with the greatest correlation to OSAS severity when inflammatory markers are assessed is the increase in MHR. Furthermore, both parameters were observed to be significantly correlated in both obese patients and non-obese patients. When logistic regression analysis was applied to assess the impact of inflammatory parameters on OSAS severity, the MHR level was identified as making a highly significant contribution $(p=0.001)$, while MLR level showed a weak level of contribution $(p<0.05)$.

When all the panels were compared with each other, the parameters with the highest correlation with increased OSAS severity were observed to be inflammatory system parameters. The lipid panel was observed to be the other highly correlated system (Figure 5). However, as there has been no similar study in the literature, this topic could not be assessed on a literature basis.

\section{Study Limitations}

Limitations of this study could be said to be that the patient groups were not assessed in terms of conditions such as hypertension or nocturnal hypoxia. However, considering the grouping according to obesity and the large amount of data, these parameters could be more appropriately assessed in future studies.

\section{Conclusion}

OSAS has a multifactorial etiology and affects many systems as disease severity increases. Therefore, to be able to improve the quality of life of these patients, assessments should not just be in terms of etiology, but the systems affected by OSAS should also be kept in mind and diagnostic studies related to these systems should be performed.

\section{Ethics}

Ethics Committee Approval: Approval for this prospective study was granted by the Local Ethics Committee (decision no: 2018-15/105) and all procedures were applied in accordance with the 1975 Helsinki Declaration.

Informed Consent: All participants were informed that their information was coded and was kept confidential.

Peer-review: Externally peer-reviewed.

\section{Authorship Contributions}

Concept: M.A., M.M., H.S., E.E.T., B.I., Data Collection or Processing: M.A., M.M., H.S., E.E.T., B.I., Analysis or Interpretation: M.A., M.M., H.S., E.E.T., B.I., Writing: M.A., M.M.

Conflict of Interest: No conflict of interest was declared by the authors.

Financial Disclosure: The authors declared that this study received no financial support.

\section{References}

1. Punjabi NM, Caffo BS, Goodwin JL, Gottlieb DJ, Newman AB, O'Connor GT, Rapoport DM, Redline S, Resnick HE, Robbins JA, Shahar E, Unruh ML, Samet JM. Sleep-disordered breathing and mortality: a prospective cohort study. PLoS Med 2009;6:e1000132.
2. Kurt OK, Yildiz N. The importance of laboratory parameters in patients with obstructive sleep apnea syndrome. Blood Coagul Fibrinolysis 2013;24:371-4.

3. Archontogeorgis K, Nena E, Papanas N, Steiropoulos P. Biomarkers to improve diagnosis and monitoring of obstructive sleep apnea syndrome: current status and future perspectives. Pulm Med 2014;2014:930535.

4. Erdim I, Erdur O, Oghan F, Mete F, Celik M. Blood count values and ratios for predicting sleep apnea in obese children. Int J Pediatr Otorhinolaryngol 2017;98:85-90.

5. Oyama J, Nagatomo D, Yoshioka G, Yamasaki A, Kodama K, Sato M, Komoda $\mathrm{H}$, Nishikido T, Shiraki A, Node K. The relationship between neutrophil to lymphocyte ratio, endothelial function, and severity in patients with obstructive sleep apnea. J Cardiol 2016;67:295-302.

6. Tokuda F, Sando Y, Matsui H, Koike H, Yokoyama T. Serum levels of adipocytokines, adiponectin and leptin, in patients with obstructive sleep apnea syndrome. Intern Med 2008;47:1843-9.

7. Inonu Koseoglu H, Pazarli AC, Kanbay A, Demir O. Monocyte Count/ $\mathrm{HDL}$ cholesterol ratio and cardiovascular disease in patients with obstructive sleep apnea syndrome: A Multicenter Study. Clin Appl Thromb Hemost 2018;24:139-44.

8. Bozkus F, Dikmen N, Demir LS. Gamma-glutamyl transferase activity as a predictive marker for severity of obstructive sleep apnea syndrome and concomitant hypertension. Clin Respir J 2018;12:1964-73.

9. Mete T, Yalcin Y, Berker D, Ciftci B, Guven Firat S, Topaloglu O, Cinar Yavuz H, Guler S. Relationship between obstructive sleep apnea syndrome and thyroid diseases. Endocrine 2013;44:723-8.

10. Gambineri A, Pelusi C, Pasquali R. Testosterone levels in obese male patients with obstructive sleep apnea syndrome: relation to oxygen desaturation, body weight, fat distribution and the metabolic parameters. J Endocrinol Invest 2003;26:493-8.

11. Petrone A, Mormile F, Bruni G, Quartieri M, Bonsignore MR, Marrone O. Abnormal thyroid hormones and non-thyroidal illness syndrome in obstructive sleep apnea, and effects of CPAP treatment. Sleep Med 2016;23:21-5.

12. Barceló A, Piérola J, de la Peña $M$, Esquinas $C$, Fuster $A$, Sanchezde-la-Torre M, Carrera M, Alonso-Fernandez A, Ladaria A, Bosch M, Barbé $F$. Free fatty acids and the metabolic syndrome in patients with obstructive sleep apnoea. Eur Respir J 2011;37:1418-23.

13. Kerley CP, Hutchinson K, Bolger K, McGowan A, Faul J, Cormican L. Serum Vitamin D Is Significantly Inversely Associated with Disease Severity in Caucasian Adults with Obstructive Sleep Apnea Syndrome. Sleep 2016;1;39:293-300.

14. Michailidis V, Steiropoulos P, Nena E, Papanas N, Maltezos E, Bouros D. Continuous positive airway pressure treatment: effect on serum lipids in patients with obstructive sleep apnoea. Open Cardiovasc Med J 2011;5:231-8.

15. Ozanturk E, Ucar ZZ, Varol Y, Koca H, Demir AU, Kalenci D, Halilcolar $\mathrm{H}$, Ozacar R. Urinary uric acid excretion as an indicator of severe hypoxia and mortality in patients with obstructive sleep apnea and chronic obstructive pulmonary disease. Rev Port Pneumol 2016;22:18-26.

16. Toyama Y, Chin K, Chihara $Y$, Takegami M, Takahashi KI, Sumi K, Nakamura T, Nakayama-Ashida Y, Minami I, Horita S, Oka Y, Wakamura T, Fukuhara SI, Mishima M, Kadotani H. Association between sleep apnea, sleep duration, and serum lipid profile in an urban, male, working population in Japan. Chest 2013;143:720-8.

17. Trzepizur W, Le Vaillant $M$, Meslier $N$, Pigeanne $T$, Masson $P$, Humeau MP, Bizieux-Thaminy A, Goupil F, Chollet S, Ducluzeau PH, Gagnadoux F, Institut de Recherche en Santé Respiratoire des Pays de la Loire (IRSR) Sleep Cohort Group. Independent association between nocturnal intermittent hypoxemia and metabolic dyslipidemia. Chest 2013;143:1584-9. 
18. Sharma SK, Kumpawat S, Goel A, Banga A, Ramakrishnan L, Chaturvedi P. Obesity, and not obstructive sleep apnea, is responsible for metabolic abnormalities in a cohort with sleep disordered breathing. Sleep Med 2007;8:12-7.

19. McArdle N, Hillman D, Beilin L, Watts G. Metabolic risk factors for vascular disease in obstructive sleep apnea: a matched controlled study. Am J Respir Crit Care Med 2007;15;175:190-5.

20. Emdin M, Passino C, Michelassi C, Titta F, L'abbate A, Donato L, Pompella A, Paolicchi A. Prognostic value of serum gammaglutamyl transferase activity after myocardial infarction. Eur Heart J 2001;22:1802-7.

21. Poelzl G, Eberl C, Achrainer H, Doerler J, Pachinger O, Frick M, Ulmer H. Prevalence and prognostic significance of elevated gamma-glutamyl transferase in chronic heart failure. Circ Heart Fail 2009;2:294-302.

22. Lee DH, Jacobs Jr DR, Gross $\mathrm{M}$, Kiefe $\mathrm{Cl}$, Roseman J, Lewis CE, Steffes M. Gamma-glutamyl transferase is a predictor of incident diabetes and hypertension: the Coronary Artery Risk Development in Young Adults (CARDIA) study. Clin Chem 2003;49:1358-66.

23. Schulze J, Lenzen $H$, Hinrichs JB, Ringe $B$, Manns MP, Wacker F, Ringe $\mathrm{Kl}$. An imaging biomarker for assessing hepatic function in patients with primary sclerosing cholangitis. Clin Gastroenterol Hepatol 2019; 17:192-9.e3.

24. Hirotsu C, Tufik S, Guindalini C, Mazzotti DR, Bittencourt LR, Andersen ML. Association between uric acid levels and obstructive sleep apnea syndrome in a large epidemiological sample. PLoS One 2013;24;8:e66891.

25. Li XP, Zhao SP, Zhang XY, Liu L, Gao M, Zhou QC. Protective effect of high density lipoprotein on endothelium-dependent vasodilatation. Int J Cardiol 2000;73:231-6.

26. Zhang Y, Li S, Guo YL, Wu NQ, Zhu CG, Gao Y, Xu RX, Dong Q, Liu $\mathrm{G}$, Sun J, Li JJ. Is monocyte to HDL ratio superior to monocyte count in predicting the cardiovascular outcomes: evidence from a large cohort of Chinese patients undergoing coronary angiography. Ann Med 2016;48:305-12.

27. Cetin EH, Cetin MS, Canpolat U, Aydin S, Topaloglu S, Aras D, Aydogdu S. Monocyte/HDL cholesterol ratio predicts the definite stent thrombosis after primary percutaneous coronary intervention for ST-segment elevation myocardial infarction. Biomark Med 2015;9:967-77. 